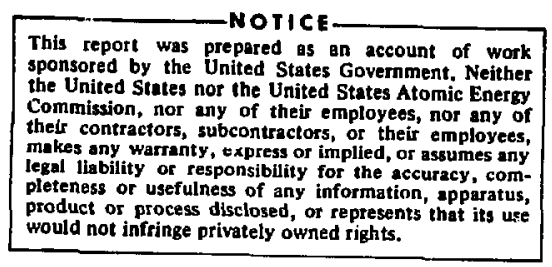

RELATTVE RISLS FROM RADIONUCLIDES FCIND

IN NUCLEARIY STIMUIATED IAATLRAL GAS*

M. J. Kelly, P. S. Rohwer, C. J. Barton, and E. G. Struxness

\author{
Environmental Sciences Division \\ Oak Ridge National Laboratory \\ Oak Ridge, Tennessee 37830
}

\title{
INTRODUCTION
}

There are rumerous pathways through which the nliclidss preseni ir. gas from ruclearly stimuiated wells can cause radiatior exposure to mar. Certain nuclides and pathways have been jesignated as critical by the Interrational Commission on Raaiological Protection (ICRP) [I] altrough. "importart" may be a more appropriate adjective than "critical."

In this paper the risks from man-made radionuclides possiojy zesent in nuclearly stimulatea natural gas are considered in three sieps: radionuclicies are ranked on the basis of their estimated radiation zose potentials; (2) projected doses expected to result from gas is comparea with estimated doses from other radiation sources; aris (3) $\because 2$. projeciions for the estimated doses are compared with cuer riscis encountered in the normal activities of life in technolcgicaliy developed nations.

It is prudent to assess the radiological impact of muclea: gas stimulation technology, because the results of this develcpment coula affect millions of people. Caution should be exercised in establising icceptable concentrations of man-made radioactivity in ratural gas for irdustrial and domestic consumption.

*Research sponsored by the U. S. Atomic Energy Commission under contract with the Union Carbide Corporation. 
Table I shows radioniclide concentrations observed in the cavity gas initially present in the Gasbuggy and Rulison experiments with estimates of the concentrations expected ir the forthcoming Rio Blanco and Wagon Wheel experiments. The right-hand column is an estimate of the average tritium and ${ }^{85} \mathrm{Kr}$ concentrations for a proposed Piceance Basin well producing $4.25 \times 10^{9}$ standard cubic feet (SCF) during the first year of production. It is estimated that Piceance Basin wells will require three 100-kiloton explosives fired sequentially.

The small number of radionuclides found a number of months after detonation is not surprising when one considers that the explosives are fired in an atmosphere of water and hydrocarbons where most of the fission and activation products exist as metals or metal oxides. The principal exceptions are the rare gases, iodine, and tritium.

Most of the radioactive species associated with metals and metal oxides are effectively retained in the glassy masses formed as the molten cavity walls solidify and collapse to form the chimney. Smith [2] attempted to detect in early Gasbuggy samples the radionuclides show in Table II and concluded they could not have existed in the cavity gas at concentrations higher than those shown. Of the radionuclides not de-

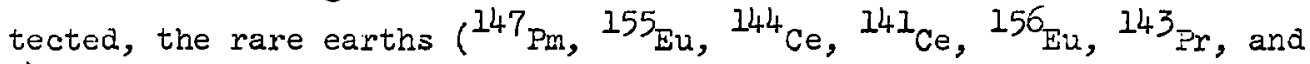
$147_{N d}$ ) may be excluded because of the low vapor pressure of their oxides. Three isotopes $\left({ }^{89} \mathrm{Sr},{ }^{90} \mathrm{Sr}\right.$, and $\left.{ }^{91} \mathrm{Y}\right)$ have rare gas precursors ano, in the elemental or oxide form, exhibit higher boilinis points than $137 \mathrm{cs}$, which also has a rare gas precursor. Thus, the strontium and yttrium isotopes would be present at a lower concentration than the upper limit shown for cesium, and our estimated concentrations for ${ }^{90} \mathrm{Sr}$ and ${ }^{89} \mathrm{Sr}$ used in this paper are not based on the experimental ${ }^{90} \mathrm{Sr}$ detection limit (1.4 $\times 10^{-3} \mathrm{pCi} / \mathrm{cm}^{3}$ ) reported by Smith [2].

Zirconium isotopes and ${ }^{11}{ }_{A g}$ would not be expected in the gas because of the low volatility of zirconium oxide and metallic silver, the most likily chemical forms of these elements in post-detonation cavities. Cadmium-115m cannot be excluded as a possible contaminant, but its low yield and 45-day half-life indicate that it should not be a significant problem. All of the other solid fission radionuclides can be excluded 
TABLE I

RADIONUCLIDF CONCENTRATIONS MEASURTD OR ESTIMATED

FOR CAVITY GAS IN NUCLFAR STIMULATION FROJECTS

\begin{tabular}{|c|c|c|c|c|c|}
\hline \multirow[b]{2}{*}{ Radionuclide } & \multicolumn{5}{|c|}{ Concentration [pCi/cc (STP)] } \\
\hline & $\begin{array}{l}\text { Gasbuggy } \\
\text { (measured) }^{a}\end{array}$ & $\begin{array}{c}\text { Rulison } \\
\text { (measured) }^{a}\end{array}$ & $\begin{array}{l}\text { Rio Blanco } \\
\text { (estimate) }\end{array}$ & $\begin{array}{l}\text { Wagon Wheel } \\
\text { (estimate) }\end{array}$ & $\begin{array}{l}\text { Piceance Basir } \\
\text { First-Year Average } \\
\quad \text { (estimated) }\end{array}$ \\
\hline${ }^{85_{\mathrm{Kr}}}$ & 123 & 150 & 205 & 140 & 60 \\
\hline $3_{\mathrm{H}}$ & 707 & $\begin{array}{c}176 \\
\text { (107 1st yr) }\end{array}$ & $<123^{f}$ & $<70^{f}$ & $<8$ \\
\hline $37 \mathrm{Ar}$ & 4720 & 6500 & $<1600$ & $<150$ & -- \\
\hline $39 \mathrm{Ar}$ & 0.085 & 1.4 & $<2$ & $<2$ & -- \\
\hline${ }^{14} \mathrm{C}$ & $0.6^{\mathrm{h}}$ & $0.41^{\mathrm{h}}$ & $<2.3^{g}$ & $<3^{g}$ & -- \\
\hline $203_{\mathrm{Hg}}$ & -- & $4.5 \times 10^{-8}$ (est) & -- & $\ll 1$ & -- \\
\hline
\end{tabular}

at detonation [2-5].

b At 90 days after detonation.

Environmental statements $[7,8]$.

at 180 days after detonation.

Reference 6 .

Water not removed.

Gydrocarbons and carbon dioxide.

hydrocarbons only. 
TABIE II

DETECTION IIMITS FOR RADIONUCLIDES IN CAVITY GAS (GAREUGGY DXIERIMENI)

\begin{tabular}{ccc}
\hline Radionuclide & $\begin{array}{c}\text { Half-life } \\
\text { (days) }\end{array}$ & $\begin{array}{c}\text { Detection Iimit } \\
(j \mathrm{C} \text { ( } / \mathrm{cc})\end{array}$ \\
\hline $127_{\mathrm{Sb}}$ & 3.9 & 2.3 \\
$131_{\mathrm{I}}$ & 8.05 & 0.04 \\
$125_{\mathrm{Sn}}$ & 9.04 & 4.5 \\
$129 \mathrm{~m}_{\mathrm{Te}}$ & 33 & $1 \times 10^{-3}$ \\
$103_{\mathrm{Ru}}$ & 41 & $8 \times 10^{-5}$ \\
$125 \mathrm{~m}_{\mathrm{Te}}$ & 58 & 0.23 \\
$123_{\mathrm{Sn}}$ & 131 & $2 \times 10^{-2}$ \\
$106_{\mathrm{Ru}}$ & 367 & $1 \times 10^{-4}$ \\
$125_{\mathrm{Sb}}^{137_{\mathrm{Cs}}}$ & 985 & $2 \times 10^{-4}$ \\
\hline
\end{tabular}

a Reference 2 . 
on the basis of yield or hali-life since a minimum of go days will occur before gas would be produced from a stimulated well.

Except for ${ }^{85} \mathrm{Kr}$, the Iission product rare gases, whose total prociction should be released to the chimney, have sufficiently short half-lives ( ${ }^{133}$ Xe at 5.27 is the most significant) that they would decay to negligible concentrations.

RANIING OF RADIONUCLIDES ACCORDING TO THEIR BIOLOGICAL SIGNIFICANCE

Consideration of the available information on probable radionuclide concentrations in cavity gas and the maximum permissible concentration in air $\left[(\mathrm{MPC})_{2}\right]$ values in Appendix B, Table II of $10 \mathrm{CFR} 20$ [9], leads to the implied ranking of these radionuclides in terms of potential dose to man listed in Table III.

The only activation radionuclides that have been observea in cavity gas are tritium, ${ }^{203} \mathrm{Hg},{ }^{37} \mathrm{Ar},{ }^{39} \mathrm{Ar}$, and ${ }^{14} \mathrm{C}$. Mercury-203 was observed early in the Rulison testing program [5] but only at a level of 1.27 $x 10^{-5} \mathrm{pC} \dot{\mathrm{I}} / \mathrm{cc}$ of cavity gas. Activation production of tritium, also a fission product, depends on constituents of the formation. It appears unlikely that any other activation radionuclide will be significant, bui each geological formation of interest as well as components of the explosive device must be analyzed with respect to this possibility.

Most of the radionuclides listed in Table III were not detected in experimental measurements, but none of these could be classed as a significant contributor to radiation exposure even at the upper limit of $i$ is estimated concentration in the gas. The remainder of this discussion is limited to those radioisotopes which have been found in nuclearly stimulated gas. Of these, ${ }^{85} \mathrm{Kr}$ and ${ }^{3} \mathrm{H}$ deserve detailed consideration, because their combined dose potential is over $95 \%$ of the total estimated dose. Using fission yields for ${ }^{85} \mathrm{Kr}$ of 0.0031 from $235_{\mathrm{U}}$ and 0.001446 from 239 Pu [10] together with the value of $1.46 \times 10^{23}$ fissions per kiloton [11], we calculate nominal yields as $25.0 \mathrm{Ci} / \mathrm{kiloton}$ for $235 \mathrm{~J}$ fission and $11.7 \mathrm{ci} /$ kiloton for ${ }^{239} \mathrm{Pu}$ fission. Using fission yield estimates for ${ }^{3} \mathrm{H}$ at $1 \mathrm{MeV}$ neutron energy of $1.2 \times 10^{-4}$ for ${ }^{235_{\mathrm{U}}}$ and $2.5 \times 10^{-4}$ for ${ }^{239} \mathrm{Pu}$ 
DOSE POTENTIAL OF SEIECTSD RADTONUCLIDES ON THE BASIS OF THEIR MAXIMUM PERMISSIBJE COICEITRATIOIT III AIR $(\mathrm{MPC})_{\text {a }}$ AND ESTIMAIED MAXIMUM CONCENTRATION IN CAVITY GAS

\begin{tabular}{|c|c|c|c|c|c|c|}
\hline Radionuclide & $\begin{array}{c}\text { Half-life } \\
\text { (days) }\end{array}$ & $\begin{array}{c}(\mathrm{MPC})_{\mathrm{a}} \\
(\mu \mathrm{Cj} / \mathrm{cc})^{\mathrm{a}}\end{array}$ & $\begin{array}{c}\text { Estimated Maximum } \\
\text { Concentration } \\
90 \text { Days Post-Shot } \\
(\mu \mathrm{C} / \mathrm{cc})\end{array}$ & $\begin{array}{l}\text { Fraction } \\
\text { of }(\mathrm{MFC})_{\mathrm{a}} \\
(\%)\end{array}$ & $\begin{array}{l}\text { Fraction of } \\
\text { Total Dose } \\
\quad(\%)\end{array}$ & $\begin{array}{l}\text { Kumerjeal } \\
\text { Rank of } \\
\text { Potertial } \\
\text { Dose }\end{array}$ \\
\hline${ }^{85} \mathrm{Kr}^{\mathrm{b}}$ & $3.75 \times 10^{3}$ & $3 \times 10^{-7}$ & $2.0 \times 10^{-4}$ & 670.00 & 54.59 & 1 \\
\hline $3_{\mathrm{H}} \mathrm{b}$ & $4.51 \times 10^{3}$ & $2 \times 10^{-7}$ & $1.0 \times 10^{-4}$ & 500.00 & 40.74 & 2 \\
\hline${ }^{14} c^{b}$ & $2.00 \times 10^{14}$ & $1.0 \times 10^{-7}$ & $3.0 \times 10^{-6}$ & 30.00 & 2.44 & 3 \\
\hline${ }^{37} \mathrm{Ar}^{\mathrm{b}, \mathrm{C}}$ & $3.41 \times 10$ & $1.0 \times 10^{-4}$ & $1.0 \times 10^{-3}$ & .10 .00 & 0.81 & 4 \\
\hline $125_{\mathrm{Te}}{ }^{\mathrm{d}}$ & $5.80 \times 10$ & $1.0 \times 10^{-8}$ & $8 \times 10^{-8}$ & 8.00 & 0.65 & 5 \\
\hline${ }^{39} \mathrm{Ar}^{\mathrm{b}}$ & $9.56 \times 10^{4}$ & $<3 \times 10^{-7}$ & $2.0 \times 10^{-6}$ & 6.66 & 0.54 & 6 \\
\hline${ }^{125} \mathrm{Sn}^{\mathrm{d}}$ & $9.4 \times 1$ & $4.0 \times 10^{-9}$ & $5 \times 10^{-9}$ & 1.25 & 0.10 & 7 \\
\hline $203_{\mathrm{Hg}}^{\mathrm{b}}$ & $4.58 \times 10$ & $2.0 \times 10^{-9}$ & $1.5 \times 10^{-9}$ & 0.75 & 0.06 & 8 \\
\hline${ }^{90} \mathrm{Sr}^{\mathrm{e}}$ & $1.02 \times 10^{4}$ & $3.0 \times 10^{-11}$ & $1.0 \times 10^{-11}$ & 0.33 & 0.03 & 9 \\
\hline${ }^{131}{ }_{I}^{\mathrm{d}}$ & $8.05 \times 1$ & $1.0 \times 10^{-10}$ & $2.0 \times 10^{-11}$ & 0.20 & 0.02 & 10 \\
\hline $129 m_{T e} d$ & $3.30 \times 10$ & $3.0 \times 10^{-9}$ & $4 \times 10^{-10}$ & 0.13 & 0.01 & 11 \\
\hline${ }^{137} \mathrm{cs}^{\mathrm{d}}$ & $9.70 \times 10^{3}$ & $2.0 \times 10^{-11}$ & $2.0 \times 10^{-11}$ & 0.01 & - & \\
\hline${ }^{89} \mathrm{Sr}^{\mathrm{e}}$ & $5.40 \times 10$ & $3.0 \times 10^{-10}$ & $1.0 \times 10^{-11}$ & 0.03 & - & \\
\hline${ }^{125} 5_{S b} d$ & $9.85 \times 10^{2}$ & $2.0 \times 10^{-8}$ & $2 \times 10^{-10}$ & 0.01 & - & \\
\hline${ }^{106} \mathrm{Ru}^{\mathrm{d}}$ & $3.67 \times 10^{2}$ & $3.0 \times 10^{-9}$ & $1 \times 10^{-10}$ & 0.03 & - & \\
\hline${ }^{123} \operatorname{Sn}^{\mathrm{d}}$ & $1.31 \times 10^{2}$ & $1.0 \times 10^{-8}$ & $\times 10^{-10}$ & 0.02 & - & \\
\hline${ }^{1.03} \mathrm{Ru}^{\mathrm{a}}$ & $4.10 \times 10$ & $2.0 \times 10^{-8}$ & $\times 10^{-11}$ & negligible & -- & \\
\hline
\end{tabular}

From Table II, Appendix B, Reference 9.

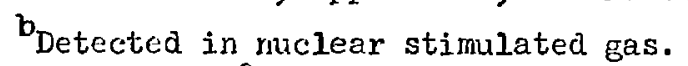

${ }^{c}(\mathrm{MIC})_{a}$ for ${ }^{85} \mathrm{Kr}$ was used.

êmimin possible concentration based on detection limit, not observed in sample analysis.

Jistjmates based on $1.37 \mathrm{Cs}$ detection limit, precursors, and chemistry. 
[12], we calulate nominal tritium yields as $0.84 \mathrm{Ci} /$ kiloton for ${ }^{235_{\mathrm{U}}}$ and $1.75 \mathrm{Ci} /$ kiloton for ${ }^{239} \mathrm{Pu}$. Tritium is, however, also produced by neutron reactions in the surrounding rock, the largesi production resulting from neutron capture by ${ }^{6}{ }_{\text {Li }}$. Green anà Lessler [13] estimate that for $10 \mathrm{ppm}{ }^{6} \mathrm{Li}$ in the surrounding rock, $500 \mathrm{Ci}$ of ${ }^{3} \mathrm{H}$ will be produced by 1 mole of reutrons. If a value of 2.5 neutrons per fission is used, this would yield $300 \mathrm{cl} / \mathrm{ktloton}$. A 10-cm polyethylene shield (25 mole $\%$ boron) could reduce this figure by an order of magnitude [13], but it appears unlikely that production of tritium by activation can be eliminated. Tritium is distributed in the $\mathrm{H}_{2} \mathrm{O}-\mathrm{H}_{2}$-hydrocarbon system with not more than $25 \%$ of the total production in the form of hydrocarbons or hydrogen. The remaining $75 \%$ appears as HTO which would normally be removed th the wellhead and must have a means for disposal.

Using these estimated tritium and ${ }^{85} \mathrm{Kr}$ production figures and the gas production figures of Rubin et al. [6], we calculate an expectea 30 to $65 \mathrm{pCi} / \mathrm{cc}$ (STP) of ${ }^{3} \mathrm{H}$ as the average radionuclide concentrations in first-year production of $4.25 \times 10^{9} \mathrm{SCF}$ of gas from a Picea.yce Basin well. These values are consistent with the production of $60 \mathrm{pCi} / \mathrm{cc}$ of $85 \mathrm{Kr}$ and less than $8 \mathrm{pCi} / \mathrm{cc}$ of ${ }^{3} \mathrm{H}$ given by Rubin et al. At the estimated production rate, more than $99 \%$ of the activity initially present in a nuclearly stimulated well is removed during the first year of production. In subsequent years, such a well produces essentially uncontaminated gas.

The ranking of potential dose contribution basea on (MPC) (Table IIJ) does not provide a true measure of the relative risk of exposures to tritium and ${ }^{85} \mathrm{Kr}$. It is often erronesusly assumed that the (MPC) alue for each radionuclide produces an equivalent radiation dose to the individual. This is not true for tritium and ${ }^{85} \mathrm{Kr}$. Tritium is a source of internal exposure with no significant external exposure potential. Tritium as HTO (the form usually present) is rapidly absorbed by the body and distributed throughout the body water pool, resulting in essentially uniform irradiation of the whole body. In contrast, krypton is only slightly absorbed by the body and the internal exposure contribution is negli g:ble. The skin dose (primarily due to beta components) is the overall limitirg factor for ${ }^{85} \mathrm{Kr}$, with the whole body dose (primarily due to gamma rays and bremsstrahlung) being approximately $1 \%$ of the skin dose. 
Ir we choose a concentration for each of these radionuclides in air of $1 \mathrm{pi} / \mathrm{cc}$, we ina a range of published doses in millirems per year as tabulated in Table IV. Radiation dose limits recommerided by the ICRP [I] for various reierence organs allow six times as much skin dose as whole body dose. If this radiosensitivity differential is applied to the dose estimated for the shalluwest layer of the live skin, the somatic risk from ${ }^{85} \mathrm{Kr}$ is less than one-tenth of the somatic risk irom tritium oxide. In addition, the significance of the skin dose is reduced by another factor of 10 because more than nine out of ten skin cancers are curable [19]. Because ${ }^{85} \mathrm{Kr}$ has low beta energy, clothing also provides protection to an extent that has not yet been evaluated. Even with these recuctions, the somatic risk from the ${ }^{85} \mathrm{Kr}$ skin dose will probably remain as large as that from its whole body dose.

It would appear that the somatic risk from ${ }^{85} \mathrm{Kr}$ is less than ore-tenth of the somatic risk from tritium at equal radionuclide concentrations, but experimental data to substantiate this conclusion are not availaole. For calculating the effective ${ }^{85} \mathrm{Kr}$ dose, we shall use $10 \%$ of the estimated dose at the skin surface. The genetic risk from ${ }^{85} \mathrm{Kr}$ is only about oneeightieth of that from tritium at equal radionuclide concentrations, and the long-term genetic effects are, we believe, more important than the somatic effects at the dose levels we are considering. If it is assumed that there would be three times as much ${ }^{85} \mathrm{Kr}$ as tritium oxide in the gas combustion proaucts, less than $25 \%$ of the estimated total somatic dose and less than $4 \%$ of the estimated total genetic aose from these radionuclides would come from ${ }^{85} \mathrm{Kr}$.

Device design can reduce the amount of tritium fcrmed, but it is considered unlikely that total tritium in cavity gas will be reauced to a point where the somatic dose from ${ }^{85_{\mathrm{Kr}}}$ will become the controlling factor. However, the dose from ${ }^{85} \mathrm{Kr}$ may represent an appreciable fraction of the man-rem dose.

Argon-39 may be combined with ${ }^{85} \mathrm{Kr}$ in considering the total effect of the radionuclides in natural gas, because it is a pure beta emitter whose energy is slightly less than that of ${ }^{85} \mathrm{Kr}$. Argon-37 with a 34.1-cay half-life will decay to a negligible activity level early in the production period. 


\section{TABIE IV}

ESTIMATED DOSE FOR ${ }^{85}$ KR AND HTO IN AIR AT

A CONCENTRATION OF $1 \mathrm{pCi} / \mathrm{cc}$ (STP)

\begin{tabular}{|c|c|c|}
\hline Exposure & $\begin{array}{c}\text { Dose } \\
\text { (millirems } \\
\text { per year) }\end{array}$ & Reference \\
\hline \multicolumn{3}{|l|}{$85 \mathrm{Kr}$ at $1 \mathrm{pCi} / \mathrm{cc}$} \\
\hline \multirow[t]{4}{*}{$\begin{array}{l}\text { Surface of skin or } \\
\text { clothing }\end{array}$} & 2093 & Kirk $[10]$ \\
\hline & 1690 & Hendrickson $[14]$ \\
\hline & 2080 & Dunster and Warner [15] \\
\hline & 1664 & Whitton $[16]$ \\
\hline $\begin{array}{l}\text { Shallowest layer of } \\
\text { live skin }\end{array}$ & 1000 & Hendrickson \\
\hline \multirow[t]{3}{*}{ Whole body } & 14.2 & Kirk \\
\hline & 23.3 & Hendrickson \\
\hline & 14.1 & Dunster and Warner \\
\hline \multirow[t]{3}{*}{ Gonadis } & 16.7 & Kirk \\
\hline & 23.3 & Hendrickson \\
\hline & 17.3 & Dunster ano Warner \\
\hline \multicolumn{3}{|l|}{$3_{\mathrm{H}}(\mathrm{HTO})$ at $1 \mathrm{pCi} / \mathrm{cc}$} \\
\hline $\begin{array}{l}\text { Surface of skin or } \\
\text { clothing }\end{array}$ & $\sim 0$ & $\begin{array}{l}\text { Turner, Kay, and } \\
\text { Rohwer }[17]\end{array}$ \\
\hline Whole body & 1825 & Rohwer and Kaye $[18]$ \\
\hline Gonads & 1825 & Rohwer and Kaye \\
\hline
\end{tabular}


The only remaining isotope of potertial dose sigripicance in tuble III is ${ }^{l h_{r}} \mathrm{C}$. Prounction of this radionuclide depencis on the decuicincompositicn os the stimulated formation but shoula be less than $2^{\text {g }}$ of the ${ }^{8} 5_{\mathrm{Kr}}$ yield. According to analyses of Casbuggy gas [2], at least two-thirds of ${ }^{14} \mathrm{C}$ activity is in the carbon dioxide reieasea from formation rock by the nuclear explosion. Carbon dioxide is normally removed from natural gas before it enters commercial distribution channels. The remaining carbon activity is bound chemically in the hydrocarbons and will be released as ${ }^{14} \mathrm{CO}_{2}$ when the gas is burned.

In terms of the somatic effect of radionuclides in nuclearly stimulated gas, tritium would, therefore, be the major contributor to the total estimated dose (rable $V$ ). The percentages shcin are arbitrary and are subject to change as nore experimental information becomes available.

\section{RADIONUCLIDE CONCENTRATION INT GAS COMBUSTION PRODUCTS}

The fact that tritium and $85 \mathrm{Kr}$ will exist in the initial vellnead gas at concentrations many times their (MPC) $a$ is cause for concers and must be considered. There are several ways of calculating minimum ailiktions: (1) Natural gas (principally $\mathrm{CH}_{4}$ ) when burned in air becomes ailuted by a factor of 17 , based on the stoichiometric amount of oxysen required. (2) The lower explosive limit is $5 \%$ gas in air which gives an effective ailution of 20 . (3) At $80^{\circ} \mathrm{F}$ only $2.50 \%$ moisture exisis in saturated air. Since two molecules of water vapor are formed from each methane molecule burned, a minimum eighty-fold dilution of tritium occurs under these conditions. Any further adaition of combustion-proâuced moisture will condense. (4) The industrial limit of carbon dioxide in air, $0.5 \%$, gives an effective dilution of 200 .

of the two real limits (mass in saturated air and the lower explosive limit), we shall use the dilution factor or 20 , based on the lower explosive limit to set a maximum allowalle concentration in natural gas. This factor applied to the present (MPC) $)_{a}$ of $0.2 \mathrm{pCi} / \mathrm{cc}$ for tritium oxide yields a maximum $3_{\mathrm{H}}$ concentration in gas of $4 \mathrm{pCi} / \mathrm{cc}$ (STP).

If one were to consider Piceance Basin development and a pipeline delivering first-year gas to Farmington, New Mexico, where i.t could be 


\section{TABLE V}

RELATIVE PERCENTAGE OF TORAI ESTIMATED SOMATIC DOSE

FROM RADIOIUUCIDES IN NUCIEARIY STIMULATED GAS

\begin{tabular}{ccccc}
\hline Radionuclide & $\begin{array}{c}\text { Average } \\
\text { Concentration } \\
(\mathrm{pCi} / \mathrm{cc})\end{array}$ & $\begin{array}{c}\text { Percentage } \\
\text { of Total } \\
\text { Estimated } \\
\text { Dose }\end{array}$ & $\begin{array}{c}\text { Concentration } \\
\text { First-Year } \\
\text { Production } \\
(\mathrm{pCi} / \mathrm{cc})\end{array}$ & $\begin{array}{c}\text { Percentage } \\
\text { of } \\
(\mathrm{MPC}) \mathrm{a}\end{array}$ \\
\hline $3_{\mathrm{H}}$ & 4 & 69 & $<20$ & $<100$ \\
$85_{\mathrm{Kr}}$ & 13 & 26 & 65 & 217 \\
$14_{\mathrm{C}}$ & 0.20 & $<5$ & $<1$ & $<10$ \\
$\mathrm{All}$ oiners & & $<1$ & $-\ldots$ & -- \\
\hline
\end{tabular}


blended with uncontaminated natural gas $6 \times 10^{8} \mathrm{SCF} /$ aay or $2.19 \times 10^{11}$ $S C F /$ year) before transmission to the west coast, one could produce gas from ten muclearly stimulated wells per year (4.25 $\times 10^{10} \mathrm{SCF}$ ) without exceeaing $4 \mathrm{pCi} / \mathrm{cc}$ at the point of use. The total amount of gas used in the Pacific Southwest in. 1970 (about $2 \times 10^{12} \mathrm{SCF}$ ) was ten times the volune of gas in the Farmington pipeline [6]. In principle, 100 new wells per year could be added to serve this region without exceeding the above limit, although achievement of uniform mixing colild be a limiting consideration. It can be seen that large amounts of nuclearly stimulated gas could be distributed through existing facilities supplemental to present production as it declines. It has been shown that the average population exposure is at least a factor of 10 less for power station gas use than when gas is distributed for household use [20]. Therefore, if estimated total population doses (man-rems) prove to be undesirably large for extensive use of nuclearly stimulated natural gas in homes, power-station use is a possible alternative.

\section{ESTIMATED WHOLE BODY DOSES}

Based on $4 \mathrm{pCi} / \mathrm{cc}$ (STP) for $3^{3}, 13 \mathrm{pCi} / \mathrm{cc}$ (STP) for ${ }^{85} \mathrm{Kr}$, and 0.20 $\mathrm{pCi} / \mathrm{cc}$ (STP) for ${ }^{14} \mathrm{C}$, we can calculate the maximum dose to an individual resulting from combustion of gas in unvented home appliances or heaters based on air saturated with moisture from combustion products at $80^{\circ} \mathrm{F}$. This condition can be realized only when unvented heaters or appliances are used under weather conditions where ventilation air contains little or no moisture ana should be coisidered calculable, but not credible. Our conversions are based on data from Table IV for $20 \mathrm{~m}^{3} /$ day air intake [21] and a 50-year whole body dose commitment from ${ }^{14} \mathrm{C}$ of $0.424 \mathrm{millirem} / \mu \mathrm{Ci}$ inhaled. The dose conversion factor used for tritium is $0.126 \mathrm{millirem} / \mu \mathrm{Ci}$ inhaled. This dose factor for tritium is based on a quality factor of 1.0 as recommended by ICRP [22], a biological half-time of 10 days for HTO in $\operatorname{man}$ [23], and the assumption that HTO vapor intake by skin absorption is equal to $70 \%$ of that by inhalation [24]. The calculated values are shown in Table VI. The dose limit for individual members of the general public (500 millirems/year) [21] would not be exceeded even for these conditions. 


\section{TABIE VI}

UPPER ITMIT DOSE ESTIMATES FOR UST OF NUCLEARLY ST: ULATED GAS UNDER SPECIFIED CONDITIONS ${ }^{a}$

\begin{tabular}{|c|c|c|c|}
\hline \multirow{2}{*}{ Raäionucliàe } & \multirow{2}{*}{$\begin{array}{c}\text { Estimated } \\
\text { Concentration } \\
(\mathrm{pCi} / \mathrm{cc})\end{array}$} & \multicolumn{2}{|c|}{ Dose Iimit (millirems/year) } \\
\hline & & Whole Body & Skin \\
\hline $3_{\mathrm{H}}$ & 4 & $<45$ & --- \\
\hline${ }^{85}{ }_{K r}$ & 13 & 3.8 & $\begin{array}{c}341 \text { (surface) } \\
163 \text { (top live } \\
\text { layer) }\end{array}$ \\
\hline${ }^{14} \mathrm{C}$ & 0.20 & $<8$ & $-\cdots$ \\
\hline
\end{tabular}

$a_{\text {The conditions assumed in making these calculations are }}$ illegal in many states and are considered very unlikely to occur. 
We reulize, of course, that one should not allow one source of exposure (in this case, the combustion of nuclearly stimlated gas in unrenteci home appliances) to take up a disproportionate share of the 500-millirem annual dose.

An extensive theoretical study of the impact of the use of nuclearly stimulated gas in the Pacific Southwest has been completed [25]. For a 1000-12 ${ }^{2}$ residence of normul construction with one air change per hour we can calculate the potential dose equivalents for various domestic uses (Table VII). These calculated values are believed to be conservative.

Many cities and states now require venting of all heaters and appliances except those used for cooking. The advent of large-scale nuclear simulation of natural gas production may require that this practice be made mandatory for all gas appliances in order to keep the population dose as low as practicable. If this suggestion is implemented, the average dose to an individual in the exposed population would be less than $0.70 \mathrm{millirem} / \mathrm{year}$ since the average atmospheric contribution from all gas used in the Los Angeles Basin has been shown to be less than $10 \%$ of the calcl lated dose from unventec cooking [20]. Even this small calculatea individual dose would deliver a potential 700 man-rem per year to each million people exposed.

It should be kept in mind, in considering this population exposure value, that a conservative assumption in regard to the tritium concentration in nuclearly stimulated gas was made in arriving at the average dose to individuais in the population group. The value used in tinis report (4 pCi/cc) can be compared with the Iigure of approximately I pCi/cc srojected for the average concentration during the lifetime production or future wells [26]. However, it should also be recognized that home use of gas containing radioactivity in unvented appliances probably involves smaller variations in estimated dose to individuals in the home than the orders of magnitude variation that occurs among individuals exposed to radioactivity dispersed in the atmosphere and in streams. In fact, transporting long-lived radioactivity into homes where the activity released from unvented appliances receives limited dilution is a situation that has not been previously encountered in actual population exposure situations from man-made radioactivity, and, accordingly, the risks must 
TABIE VII

EXYECTED AVERAGE WHOLE BODY DOSH EQUTVALFNTS FROM HYPOTHETICAI DOMESTIC USEŚ

OF NUCJEARLY STIMULATETI GAS

\begin{tabular}{|c|c|c|c|c|c|}
\hline \multirow[b]{2}{*}{ Radionuclide } & \multirow{2}{*}{$\begin{array}{c}\text { Estimated } \\
\text { Concentration } \\
(\mathrm{pC} j / \mathrm{cc})\end{array}$} & \multicolumn{4}{|c|}{ Whole Body Dose (millirems/year) } \\
\hline & & $\begin{array}{l}\text { Unvented } \\
\text { Cooking }\end{array}$ & $\begin{array}{l}\text { Unvented } \\
\text { Water Heater }\end{array}$ & $\begin{array}{l}\text { Unvented } \\
\text { Refrigerator }\end{array}$ & $\begin{array}{l}\text { Unvented, } \\
\text { Heating }\end{array}$ \\
\hline${ }^{3} \mathrm{H}$ & it & 0.5 .1 & 2.21 & 0.64 & 4.50 \\
\hline${ }^{85} \mathrm{Kr}$ & 13 & 0.04 & 0.09 & 0.05 & 0.37 \\
\hline${ }^{1 / 4} \mathrm{C}$ & 0.20 & 0.09 & 0.21 & 0.1 .1 & 0.76 \\
\hline Total & & 0.64 & 1.51 & 0.80 & 5.63 \\
\hline
\end{tabular}

Illegal in many states.

Based on estimates made in Colorado and sales of gas refrigerators, it is estimated that less than $2 \%$ of United States homes have gas refrigerators.

c500-degree days. 
be carefully examined and evaluated before large population groups are exposed in this manner. Fortunately, the concentration of radioactivity in gas transmitted in pipelines can be monitored continuously and absolute control can be exercised on the concentration permitted in homes. In addition, if the concentration cannot be reduced to acceptable levels by dilution before reaching the homes, it could be diverted to electric gerierating plante where the ovefall man rems expeoted to bo ativered to the population would be considerably less (and, hopefully, acceptable).

ASSESSMENT OF THE ESTIMATED AVERAGE WHOJE BODY DOSE

Assessment of the dose estimate projected for use of gas from nuclearly stimulated fields can vary in form and complexity, reflecting the perspective of the person performing the analysis and the reason for the assessment. Our first assessment is a cumparison of the dose estimate with applicable radiation safety standards.

At this time, there are no standards which are specific io the use of nuclearly stimulated gas. The Federal Raciation Council (FRC) established 500 millirems/year as the upper limit for whole body dose to ixdividual members of the population and 170 millirems/yaar as the upper limit for the average whole body cose to a suitable sample of an exposed population group for radiation from all sources exclusive of natural backgrouna ana medical exposure [27]. The FRc further recommends that every reasonable effort be made to keep exposures as far below these levels as practicable. Some apportionment of these dose limits among the many potential sources of exposure has been suggested. Brodsky [28] provides a framework for halancing and controlling the allotment of radiation exposure from consumer items on the basis of' a benefit-risk assessment, but he gives no speciric values applicable to our case. Morgan [29] suggests apportionment of the specified 170-millirem limit as: nuclear power operations, 67 millirems; other industrial operations, 45 millirems; medical, 50 millirems; occupational, 4 millirems; weapons fallout, a millirems; and miscellaneous, 2 millirems. Regardless of the allocation method used, the estimated average whole body dose for the population group expected to be exposed via home use of nuclearly stimulated gas is a small fraction $(0.4 \%)$ of the dose limit of $170 \mathrm{millirems} /$ year. 


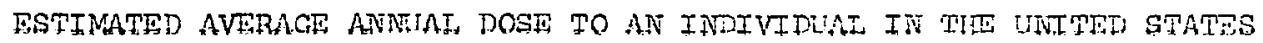
FROM NATURAI AND MAN-MADE RADIATION SOURCES

\begin{tabular}{|c|c|c|}
\hline Source of Radiation & $\begin{array}{l}\text { Estimated Dose } \\
\text { (millirems/year) }\end{array}$ & Referexces \\
\hline \multicolumn{3}{|l|}{ Natural Sources: } \\
\hline Terresirial radiation ${ }^{a}$ & 70 & $27,30,31$ \\
\hline Cosmic radiation ${ }^{b}$ & 30 & \\
\hline \multicolumn{3}{|l|}{ Man-Nade Sources } \\
\hline Meäical àiagnositic $x$-rays ${ }^{c}$ & 110 & $27,30,32$ \\
\hline Fallout from nuclear weapons & 2 & 33,34 \\
\hline Corsumer devices & & 27,30 \\
\hline Indistrial uses of radiation & $<1$ & 35 \\
\hline Power reactors ${ }^{f}$ & $<1$ & 32,36 \\
\hline
\end{tabular}

Pxternal exposure contributes about 50 millirems ana internal exposure about 20 millirems.

$b_{\text {External exposure at sea level. }}$

Based on an assumed genetically significart dose $0: 36 \mathrm{milli-}$ rems per year, with the further assumption that the efiective somatic dose is approximately three times the genetically signiricant dose.

Internal exposure per year averaged over the lifetime of an isdividual.

External exposure from television sets, luminous dial watches, etc.

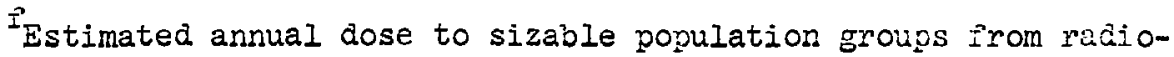
activity released in effluents from all light water-cooled nuciear power reactors on all sites in the united States through the year 2000. 
TABIE IX

THEOREIICAI RISK ESTIMATES FOR RADIATION INSULIS AT IOW DOSE RATES

Calcuiatec

Type of Risk Mortality Probability

Somatic Insult

All types of cancer

$10^{-4} /$ person/rem

Monspecific Iife shortening

$5 \times 10^{-5} /$ person $/$ rem

Genetic Insult

First-generation

$2 \times 10^{-5} /$ person $/ \mathrm{rem}$

genetic deaths

Total genetic deaths

$7 \times 10^{-4} /$ person $/$ rem 


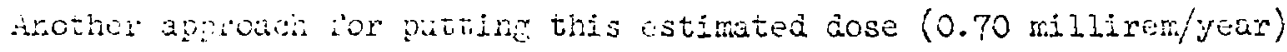
in perspective is to compare it with dose estimates for other exposures received by memors of the united States public (see Taile viII). The values presented in this table are averages for the entire inited staues population, but the major portion of the dose estimated from nucieariy stimilatea gas (for unvented cooking) wolic be receivea only by that segment oi the population utilizing the gas in this manner. Tre dose attributed to natural sources varies considerably with geographic location; the terrestrial component is estimated to range from 30 to $200 \mathrm{millirads/year,}$ the cosmic component from 30 to $100 \mathrm{millirads} / \mathrm{year}$. The unnual whole body dose projected for home users of natural gas from nuclearly stimulated gas fielas is approximately $0.5 \%$ of the average dose of $130 \mathrm{millinems} / \mathrm{year}$ receivea by members of the United States population from natural background radiation reported in a recent survey [37]. In comparison with man-made radiation sources, the estimated whole body cose due to meaical diagrostic $x$-rays in 1970 approximately equals the background rasiation dose shown in Table VIII and thus is 160 times larger than the projected acse to the average naturil gas user (as developed in tris report). In contrast, the individual dose estimates for fallout and for consumer device raciation are approximately three times the average dose estimated for members of the hypothetical gas-using population.

A more complex, although largely hypothetica?, assessment of the projected dose from use of nuclearly stimulated gas is obtairea by estimating the risk which the exposure represents in terms of aciaitional theoretical deaths, aduitional theoretical death equivalents due to radiation-inaluced life span shortening (For this calculation, 70 years of life shortening equals one death.), and additional theorecicai genetic deaths. The risks (theoretical deaths) may then be compared with krown death rates among the United States population from other causes. The term "theoretical death" is used becaluse the calculation results in wat is believed to be an upper limit of risk for the low average dose leveI ( $0.70 \mathrm{millirem} / \mathrm{year}$ ) calculated in this paper. The factors used to convert estimates of radiation dose into estimates of risk (see Table IX) are those suggested by the ICRP [38, 40]. It is important to note that these factors are based on the conservative assumption that there is a linear relationship between dose and effect. The actual risk in fact 
my be zero. However, it suce low sosos, there is ro practicil mettos

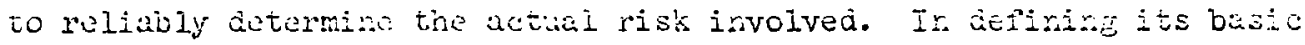
concefts, the ICRP has stated "that the permissible doses for occupational workers* can 'be expectec to prowuce effects which could be detected only by statistical methods applied to large groups.' This circumstance would by itself create great difficulty in evaluating, by direct ooservation, the rijks ittendute on theso lovels ol exposure; in practice the problen is made considerably more difficult because the same types of injury arise frequently irom other and unikentified causes. The only practical approach is an indirect one, namely, to assume that the response per unit dose at very low doses is the same as that observed at the consiaerably higher levels of exposure For thich reasonably quantitative observatior is possible. This procedure, as the United Nations Scientific Crmititee on the Effects of Atomic Radiation has recently concludea, is likely in the majority of cases to inaicate an uppex limit of risk because 'it is unlikely that the risk per unit dose at very low doses will be ary greater than at high doses and likely to be much less." A further source of uncertainty is that in the assessment of genetic risks it is recessary to cieperä almost entirely on observations made on organisms otrer than $\operatorname{man}^{\prime \prime}[40]$.

The theoretical nonspecific life shortening accounts for increased mortality following raaiation exposure of populations, mortality which is not specifically associated with any disease but would appear as an accelerated aging process. It should be understood that the expression $\mathrm{O}^{*}$ geretic insult in terms of numbers of theoretical deaths is not the same as the calculated somatic death. A genetic death may be ieineà as the eventual loss of a gene lineage (e.g., reduced fertilicy, sterility of a person carrying the gene, stillbirth, abortion, and prereprodlictive aeath). The basic assumption is that each genetic mutation everiualy results in a calculable "death." Some "deaths" will occur in the irirst generation, but a large majority will occur in succeeding generations. Risk estimates calculated for the projected use of natural gas from malearly stimulated wells are presented in Table $X$. The estimates ror

*The authors of this report point out that the dose limits for members of the public are one-tenth the permissible doses for occupational workers. 


\section{TABIE X}

UPPER IIMIT ESTIMATES OF ADDITIONAL DEATHS EXPECTED TO RESUTT BROM THE RADIATION DOSE (0.70 NILIIREMS PER YEAR) FECEIVED PROU TEE HYPOTHETICAI HONE USE OF NUCLFARLY STIMULATED NATURAI GAS

Theoretical "Deaths" per Year Type of Radiation Damage per Million Gas Users
a. Cancer
0.07
b. Jonspecific life shortening
0.03
c. Genetic (irirst generation)
0.01
a. Genetic (future generations) ${ }^{2}$
0.5
Total "deaths" per year (a+b-c)
0.1
Total "deatis" introduced into population each year $(a+b+a)$
0.6

ajper limit of estimate of risk from recessive mutations. 
TABLE XI

COMPARISON OF ISTIMATED DEATHS IN THE UIMTED STATES FOFTIATIOT DJE TO NATUFAL BACKGROUND AND MAN-MADE RADIATION WITH DEATFS DUE TO OIFER CAÜSTS

\begin{tabular}{|c|c|c|}
\hline Causes. of Death & $\begin{array}{l}\text { Number or" } \\
\text { Deaths }\end{array}$ & Rate $^{\text {iz }}$ \\
\hline All causes & $1,930,032$ & 9660 \\
\hline Heart àisease & 744,658 & 3730 \\
\hline Cancer & 318,547 & 1590 \\
\hline Stroke & 211,390 & 1060 \\
\hline Accidents & 114,864 & 570 \\
\hline Pneumonia & 66,430 & 330 \\
\hline Diabetes mellitus & 38,352 & 190 \\
\hline Arteriosclerosis & 33,568 & 170 \\
\hline Natural backgrouna radiation & 3,400 & 17 \\
\hline \multicolumn{3}{|l|}{ Man-made sources of radiation } \\
\hline Medical diagrostic $\mathrm{x}$-rays & 4,000 & 20 \\
\hline Pallout from nuclear weapons & 80 & 0.4 \\
\hline Consumer devices & 80 & 0.4 \\
\hline Nuclearly stimulated natural gas ${ }^{c}$ & & 0.1 \\
\hline Industrial lises of radiation & $<40$ & $<0.2$ \\
\hline Power reactors & $<40$ & $<0.2$ \\
\hline
\end{tabular}

Deaths per million population, known or calculated (for all types of radiation).

${ }^{0} 0.1$ rem per year.

Based on this study. 
spoilic types of radiation damage presented in the upper portion of the table are atided to obtain the total estimates river in the low portion.

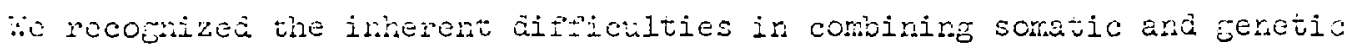
insults wose manilestations may differ so greatly, in making these estimates. Otway et al [42] sugrested that calculatior of raâiation-indicea mitation frequency (genetic death frequency as calculatea here) is mearinfful only in comparison with the natural rate of mutation. Finey inaicate that the natural geretic death rate, based on normal mutation rates and gentic equilibrium, may be estimated as 0.2 per person per generation [42]. If 30 years is assumed to be the mean age for child bearing, the estimated geretic insult from continuous radiation exposure via use oi natural gas containing low levels of radioactivity during that 30 -year period is approximateiy $0.01 \%$ of the above-cited estimate for the natural genetic deatr. rate.

The risk estimated for the projected gas usage is compared in Table KI with sinilar estimates of risk for other sources of radiation exposure of the public. Death rates associated with other risks encounterea in the rormal activities of life in the United States are proviats for comparison [43]. The intent is to give perspective and not to minimize the significance of the possible risk to man from the use of nucleariy stimilated natural gas, although the raaiation dose and the associatec rish may be small in comparison with some other risks. The use of nucleariy stimilated gas assumed in this hypothetical analysis is reasonable, ard ac resilis of the Sose assessments iraicate that the impact is acceptabi small. All radiation exposure should be scrutinized in the interest of ce: dose "as low as practicable." There is a resporsibility to as ass the impact of the estimated radiation exposure, to place the assessment ir. perspective, ard to present it is a form which can be understood by all interested parties. The radiation risk associatea with the use of miclearly stimulated gas needs to be studied as an integral part oi tre cost-berezit analysis in development of nuelear gas stimulatio: iecr:aloy. 


\section{REFEREICES}

[1] International Commission on Radiological Protection, Principles or Environmental Nonitoring Related to the Handling of Radioactive Materials (Report of Committee 4), ICRP Publication 7, Pergamon Press, London (1966).

[2] SMTH, C. F., Project Gasbuggy Gas Quality Analysis and Evaluation Program, Tabulation of Radiochemical and Chemical Analytical Results, USAEC Report, UCRL-50625, Rev. 2 (April 197I).

[3] SIMTH, C. F., "Chimney gas radiochemistry in nuclear gas stimulation applications," Nuclear Tech. 15 (1972) 85.

[4] REYTOLDS, MILES, JR., "Project Rulison--Summary of results and analyses," Nuclear Tech. 14 (1972) 187.

[5] GOTCHY, R. L., Project Rulison Final Operationsl Radioactivity Report, Production Tests, IVO-112 (February 1972).

[6] RUBIN, B., et al., An Analysis of Gas Stimulation Using Nuclear Explosives, USAEC Report UCRI-51226 (May 1972).

[7] Envirormental Statement, Rio Blanco Gas Stimulatior. Project, WASH1519 (May 1972).

[8] Environmental Statement, Wagon Wheel Gas Stimulation Project, WASH1524 (April 1972).

[9] Stanaards for Protection Against Radiation, Tíle 10, Cade of Federal Regulauions, Part 20.

[10] KIRK, W. R., Krypton-85, A Review of the Iiterature and ar Analysis of Radiation Hazards, Environmental Protection Azency, CFfice of Research and Monitoring, Washington, D. C. 20460 (January 1972).

[11] TELIIR, E., et al., The Corstructive Uses of Nuclear Explisives, . McGraw-Hill Book Company, New York (1965) 90.

[12] DUDEY, N. D., Review of Low-Mass Atom Production ir Fast Reactors, ÜSAEC Report ANL-7434 (1968).

[13] GREEN, J. B., JR., ana LESSISR, R. M., Reduction of Tritiura from Unâerground Nuclear Explosives, UCRI-73258 (Septemoe\% i9?2).

[14] HENDRICKSON, M. Vi., The Dose from $85 \mathrm{Kr}$ Released to the Eirth's Atmosphere, BNWL-SA-3233A (Juily 1970).

[15] DUNSTER, H. J., and WARNER, B. F., The Disposal Oi rioble Gas Fission Iroducts from the Reprocessing of Nuclear Fuel, British repor: AHSB (RP) R101 (January 1970). 
[16] WHITron, J. T., MRS., Dose Anjing from Inhalation of Noble Gases, British report $\mathrm{RD} / \mathrm{B} / \mathrm{N} 274$ (Decemier 1968 ).

[17] TURNER, W. DOYEE, KAYE, S. V., and ROHWER, P. S., TXREV and INEEY Compiter Cocies for Estimating Radiation Doses to Populations from Corstruction of a Sea-Ievel Canal with Truclear Explosives, USA Report K-1752 (September 16, 1968).

[18] ROHWER, P. S., and KAYE, S. V., Age-Dependent Models for Estirating Irternal Dose in Feasibility Evaluations of Plowshare Events, USAEC Report, ORNI-TM-2249 (1968).

[19] American Cancer Society, 2967 Carcer Facts and rigures (19607).

[20] JACOBS, D. G., et al., Theoretical Evaluation of Consumer Products from Project Gasbuggy, Final Report, Phase II: Hypothetical Population Exposures Outside San Juan Basin, USAPC Report ORNL-4.748 (February 1972).

[21] International Commission on Radiation Protection, Report of Committee II on Permissible Doses for Internal Radiation, ICR P Publication 2, Pergamon Press, Niew York (1959).

[22] International Commission on Radiological Protection, "Progress Report from ICRP," Health Physics 17 (1969) 389.

[23] International Commission on Radiological Protection, Recommenaations or the International Commissior on Reàiological Protectior. (Repori of Committee IV on E'valuation of Raciation Doses $\tau$ is boc̀y Tissues from Internal Contamination Die to Occupational Exposure), ICX? Püjlication 10, Pergamon Press, London (1968).

[24] OSBORNE, R. V., "Permissiole levels of tritium in mar and the entionmerit," Radiation Res. 50 (1972) 197.

[25] JACOBS, D. G., et al., Theoretical Evaluation of Consumer Products from Project Gasbuggy, Final Report, Phase I: Impact of Hypothetical Releases of Contaminated Gas in the San Juan Basin, USAEC Repori, ORNL-4646 (September 1971).

[26] BARTON, C. J., et al., "Radiological considerations in the use o: natural gas from nucleariy stimulated wells," Nuclear Tech. 11 (157i) 335.

[27] Federal Radiation Council Report No. 1, Background Vaterial for ine Developraent oż Radiation Protection Standards (May 1960). 
[28] BRODSKY, A., "Balancing benefit versus risk in the control of consumer items containing radioactive material," American Journal of Pubiic Ilealth 55 (December 1965) 12.

[29] MORGAN, K. Z., "Symposium: Radiation legislation--its meaning to the radiologist," Radiology 29(3) (1971) 569-588.

[30] United Nations Scientific Committee, Report on the United Nations Scientilic Committee on the Effects of Atomic Radiation, Cereral Assembly, Seventeenth Session, Supplement 16 (A/5216) (1962) 20.

[31] United Nations Scientific Committee, Report of the United Nations Scientific Comittee on the Effects of Atomic Radiation, General Assembly, Twenty-First Session, Supplement 14 (A/6314) (1966) 3.

[32] MORGAN, K. Z., "Comparison of radiation exposure of the population from medical diagnosis and the nuclear energy industry," presented at the American Nuclear Society meeting, Las Vegas, Nevada, June 22, 1972.

[33] Federal Radiation Council, Estimates and Evaluation o* Faliout in the Unitea States from Nuclear Weapons Testing Conductea Through 1962, Report No. 4, Superintercient oi Docurents, $z$. Printing Office, Washington, D. C. 20402 (Way 196́s).

[34] SHLEIEN, B., "An evaluation of internal raăiation exposune basea on àose commiments from raūionucliâes in milk, food, ana air," Health Physics 18 (1970) 266.

[35] GuSTAFSON, P. $F$. , "Exvirormental raciation, past, preseri, anci future," IEEE Transactions on Nuclear Science is-ig(1) (February 1972) 106.

[36] ROGZRS, I. R., Statement presentea at AFC rule-making neurings or effluents from light-water-cooled nuclear reactors, Germantom, Marylanà, Docket lio. RM-50-2 (January 1972).

[37] KCEUENT, A. W., et al., Estimates of Ionizing Radiatior. Joses in the United States, 1960-2000, ORP/CSD 72-i (August 1979: 1\%.

[38] International Commission on Raciological Protection, Raúiosensizivity c:a Spatial Distribuition of Dosa, ICRP Publication 14, Pergamo: Press, New York (1969).

[39] International Commission on Raciological protection, Recommendaticns of the International Commission on Radiological Protection, ICKD Publication 1, Pertgamon Press, New York (1959). 
[40] Intcrutional Commission on Raiological Protectich, The Evaluation.

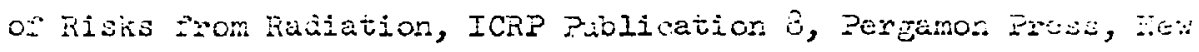
Yoris (1906).

[41] Interrational Commission or. Rajiclogical Protectich, Recometiaticas of the International Commission on Rauiological Protection (acioted Siptember 17, 1965), ICRP Publication 9, Pergamon Press, Nen rori (1966) 9.

[42] OTWAY, H. J., LOHRDING, R. K., ana BATTAT, M. E., "A risk estimate for an urban-sited reactor," Whiclear Tech. 르 (Octcber 1971) 173-10́4.

[43] National Safety Council, Acciaent Facts, Chicago, Iilinois (1971). 